\title{
Gods, Games, and the Socioecological Landscape*
}

\author{
Benjamin Grant Purzycki ${ }^{1}$, Theiss Bendixen, Aaron D. Lightner \\ Dept. of the Study of Religion, Aarhus University, DK \\ Richard Sosis \\ Dept. of Anthropology, University of Connecticut, USA
}

\begin{abstract}
The social sciences have long recognized a relationship between religion and social ecology. Upon closer inspection, religious systems not only correspond to important features of a society's social ecology, but also appear to directly address these features. In this article, we examine the prospect that these salient features may be framed as game theoretical dilemmas and argue that contemporary approaches that emphasize cognition and/or social learning at the expense of social ecology are inadequate in accounting for cross-cultural variation in religious expression. Using ethnographic examples, we show that religions alleviate the costs of such dilemmas in a variety of ways by: 1) fostering beliefs that motivate and sustain beneficial practices; 2) incentivizing cooperative ventures; 3) encouraging ritual performances that minimize costly conflicts and bolster territorial conventions; 4) providing institutional forums to coordinate resource distributions; and 5) maintaining important resource and species diversity.

Keywords: religion, game theory, supernatural punishment, ritual, cooperation, coordination
\end{abstract}

${ }^{\star}$ This article is an expanded and revised version of Chapter 10 in Purzycki \& Sosis $(2022)$.

${ }^{1}$ Corresponding author email: bgpurzycki@cas.au.dk

Preprint submitted to Curr. Rsch. in Ecol. and Soc. Psych.

June 1, 2022 


\section{Introduction}

2 Following others (Jensen, 2019: Tylor, 1920: Wallace, 1966), we theoretically 3 define religions as practices done to engage with and alter the states and atti4 tudes of spiritual agents. If we adhere to this definition and proceed to examine 5 the cross-cultural variation in those practices and their associated beliefs (e.g., the objective costs, timing, and spatio-temporal distribution of ritual, or beliefs about what pleases and angers the gods), at least two things become clear. First, religion is a human universal. That is, although their forms and content may vary tremendously along a wide range of dimensions, all societies have practices conducted in relation to supernatural beings. A second fact-if perhaps less widely appreciated than the first - is that features of religious traditions evolve in ways that conform to communities' socioecological conditions Purzycki \& 13 Sosis, 2022. In this paper, we frame these socioecological conditions formally 14 as cooperative dilemmas and closely examine ethnographic cases to illustrate 15 this correspondence and how we might proceed with an evolutionary approach to religious variation. We also briefly discuss a general evolutionary process account by which religions achieve this correspondence.

Observing these patterns, many cultural anthropologists have appreciated that each of these elements interrelate in a kind of systemic cultural logic of meaning (Geertz, 1973, Rappaport, 1999, Spiro et al., 1987). Consistent with pur other work Alcorta \& Sosis, 2005, Bendixen et al., in press, Lightner \& Purzycki, n.d. Purzycki \& Sosis, 2022), we treat religions as systems of both information and energy, positing that their content and structure flexibly adjust to novel conditions, and that variation in religion is partly explained by these conditions. In order for religious systems to function as cohesive, adaptive systems, their elements must inform and respond to each other. By re-routing 27 the allocation of resources into collective and other ritual acts with signaling 28 functions, religions inhibit the kinds of selfishness that would otherwise plague social life. In light of systems' constituent parts informing each other, simple accounts that appeal solely to cognition and/or social learning, for example, are 
insufficient.

If there is a correspondence between religions and social ecologies, we should expect the cultural evolution of religious traditions to be in certain respects dissimilar to that of, say, linguistic accents, fashion trends, or ice cream preferences. In such cases, historical contingency, social learning processes, and evolved cognition explain the bulk of the variation. The evolution of religion, by contrast, is more likely to resemble other cultural adaptations such as foraging strategies and domicile constructions. Historical contingency, social learning, and cognition may explain some variance, but phenotypic design is largely a function of a particular set of socioecological conditions (Bendixen et al., in press, Bendixen \& Purzycki, 2020, Purzycki \& Sosis, 2022). In realtime, particular religious contexts might proximately trigger cognitive mechanisms such as agency detection Andersen, 2019, Guthrie, 1995) and corollary moral cognition (Boyer, 2000, Purzycki et al., 2022). Enculturation and sharedness are also critical; we teach each other when and where to engage these systems through religious thought and practice. However, many of the important features of any social system are also things that are not explicitly transmitted socially, such as the emergent properties of such systems' interacting components (Sosis, 2019) and the variation in payoff structures of different socioecological contexts. The ecological inputs to cognitive-cultural systems are critical for accounting for the content and form of religious traditions exhibited around the world.

To situate our discussion in a more formal evolutionary theory, we frame specific ethnographic examples using game theoretical payoff matrices. While classical economic game theory (Von Neumann \& Morgenstern, 2007 [1944]) emphasizes the individual decision-making, evolutionary game theory (Maynard Smith, 1982 ) models the change in frequency of competing - and interacting - behavioral strategies in social dilemmas. Formal theory suggests that cultural strategies can evolve in response to different games (Bednar \& Page, 2007), thus generating relatively stable cooperative groups.

Many have appealed to and/or applied game theory and game theoretical payoff structures to address various aspects of religion. Among these include: 
theological questions (Brams, 2007, 2018; Hacking, 1972), the phylogeny of animistic cognition (Guthrie, 1995), the relationships between religion and cooperation (Blum \& Dudley, 2001; Bulbulia, 2004a b; Bulbulia \& Frean, 2010, Nesse 1999, Orbell et al., 1992, Pasquino, 2001: Schelling, 1968: Weingast, 1995), managing commons problems with religious appeals and practices (Atran et al. 1999, Lansing \& Kremer, 1993 , Lansing, 2006; le Guen et al., 2013, Sosis, 2003), and supernatural punishment more generally (Brams, 2007, Johnson \& Krüger 2004). Building on this work, we wager that considerable variation in religious systems can be accounted for by virtue of their flexible adjustments to local problems.

To illustrate this, we examine specific ethnographic examples and show that in a variety of ways, important cross-cultural variation in religious systems can be accounted for in relation to the social ecologies in which they are embedded. The next section situates religious systems in four disparate socioecological contexts: 1) field-burning (Martu of Australia); 2) rice-terrace irrigation (farmers of Bali); 3) territoriality (Tyvans of southern Siberia); and 4) forest foraging (Batak of the Philippines; Itza' Maya of Guatemala). We frame these case studies in game-theoretical terms and point to how religious beliefs and practices influence how people interact in and with these games in a variety of ways ${ }^{2}$ We then turn to some brief examples of recent changes in the content and form of religious systems, discussing them in light of this framework. We conclude with prospects for future directions in the evolutionary, biocultural, and cognitive sciences of religion.

\footnotetext{
${ }^{2}$ Note that our analysis diverges from many discussions that emphasize the anonymity afforded by particular environments that might increase the temptation to defect (e.g., urban communities or widely disbursed communities) (see Johnson, 2005, 2016 Norenzayan 2013). Here, we focus on the local socioecological problems among societies that have largely been underemphasized in the literature.
} 


\section{Gods, games, and socioecologies}

\subsection{Martu field-burning}

The indigenous Martu of Western Australian burn fields in a controlled manner. This practice has the effect of reducing the sizes of natural and less controllable fires, such as from lightning strikes. It also enriches the soil, aiding the growth of seed-producing plants upon which smaller animals feed and so increases species diversity. These animals are prey for monitor lizards which, in turn, the Martu hunt. In this system, controlled burning increases the availability of resources for people over the long term. Bird et al. (2013) modeled this system, as illustrated in Figure 1. Note that each arrow in the figure represents a tractable, empirically testable relationship. Indeed, the authors subsequently found that compared to otherwise untouched areas, hunting is more successful where the Martu burn. Here, then, we have a system of niche construction (Kendal et al., 2011; Laland et al., 2016) and foraging behaviors that co-vary with measurable gains.

What about the role of religion? In our view, what qualifies Martu field burning as "religious" is that the Martu justify this practice with appeals to "the dreaming" and the will of ancestors. According to the authors, such beliefs "are the institutionalization of... histories of ecological practice" (Bird et al., 2013, $6)$, thus implying that these practices are maintained in part by religious appeals. In other words, the Martu imbue these practices with religious meaning, reducing energetic and informational uncertainty and thereby increasing efficiency (North, 1990, 1991). Further bolstering the significance and predictability of burning, some Martu hold that the stakes are quite high:

Critical to the perpetuation of life is the proper adherence to the Law...[that] frames the importance of hunting and sharing within the notion that 'country must be used and appropriately burned' if life is to continue. As one elder put it, to stop using up resources, to stop hunting and burning, would mean 'the end of the world' (Bird et al. 2016, S71). 


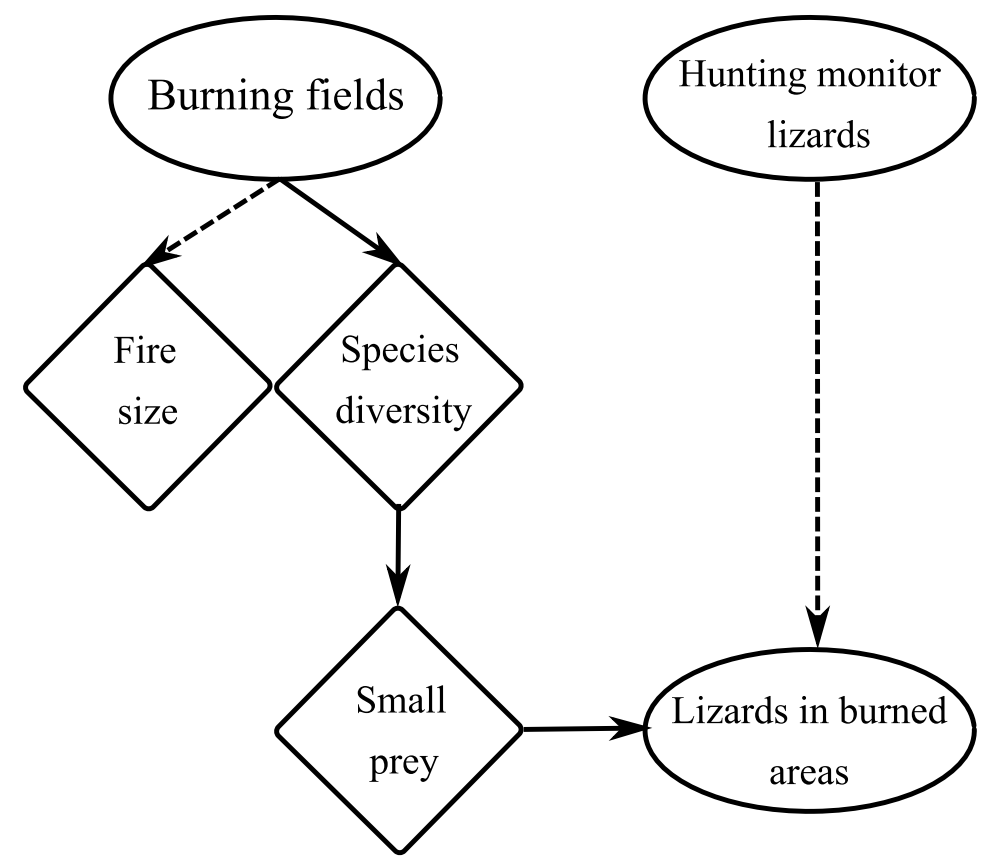

Figure 1: Martu field burning system (adapted from Bird et al. 2013). Solid lines are positive inputs and dashed lines are negative inputs.

And finally, successful hunting means successful sharing: "hunting is always embedded in a context of social exchange... the goal is not to eat more but to share more to other members" of the group (ibid.: S73). Successful hunting affords some status to the hunter, but it also facilitates the development of an individual's cooperative network through trusting relationships (Bird \& Power 2015). Burning fields to maintain the Law and the wills of ancestors clearly provides caloric gains for individuals and their communities. The collapse of this system, ceteris paribus, might very well entail the cessation of the Martu's social ecology.

There are two things to note here. First, even though the ethnographic descriptions of Bliege Bird and colleagues (also see Tonkinson, 1991) suggest that field burning is religiously inspired and maintained, the role of religious cognition and beliefs in this system remains unclear and unmeasured. But if 
we could toggle beliefs among the Martu, what would happen to field burning practices over time? Would the lack of divinely inspired motivations make the system appear impractical or unproductive (Johnson, 2005)? The collapse of the Tambaran cult among the Ilahita Arapesh of New Guinea, for example, transformed garden work, which had provided subsistence for the Arapesh and their ancestors, from a "meaningful endeavor into unredeemed drudgery" (Tuzin, 1997, 34), resulting in reduced work efforts and productivity. Would the Martu system suffer a similar fate if religious beliefs were altered or eliminated?

Imagining such scenarios raises an obvious question: why not instead make secular appeals - that is, appeals that do not point to a transcendent order - to maintain the Martu field burning system? Would it disintegrate sooner because secular rationales are easier to manipulate and alter, or because the authority of gods is generally perceived to be more powerful than human authority (Rappaport, 1999, Rossano \& LeBlanc, 2017, Sosis \& Bressler, 2003)? While ethnographers characterize Martu cosmological beliefs about field burning as institutionalized, which implies sharedness, researchers have not examined why the Martu have not institutionalized this system in a secular way (e.g., "we have always done this to get more lizards").

The second thing to note is that while this system functions to extract more energy from the environment, and increasing resources might fuel more cooperation among individuals embedded in this system, Bliege Bird et al.'s model does not address the potential social dilemma(s) implicated in this process. Why burn at all? We might analyze the task of getting people to collectively participate in field burning as a coordination problem. Table 1 frames the payoffs involved in getting people to collectively burn as a "stag hunt" dilemma (Rousseau, 2016 [1755]; Skyrms, 2004, Bulbulia, 2011, 2012). In this dilemma, one has to choose between a smaller but more reliable payoff and a larger but less reliable one. More specifically, since it is costly to hunt, and bigger game (i.e., the stag) can only be captured with the assistance of a partner, it is better to hunt for big game only when your partner does. In other words, it pays to look for smaller game (e.g., a rabbit) on your own when others won't contribute 

capita net benefits.

\begin{tabular}{ccc}
\hline \hline & Burn & Don't Burn \\
\hline Burn & $b$ & 0 \\
Don't Burn & $s$ & $s$ \\
\hline \hline
\end{tabular}

Table 1: Payoff matrix for coordination in Martu field burning. Payoffs are for player on left side of table.

to hunting larger game, even when hunting larger game would yield higher per

In the case of the Martu, individuals in the model can choose to participate in collective burning or not. Here, the benefits of burning collectively, $b$, include the aforementioned lizards. Hypothetically, if a Martu chooses to burn without help, she is unable to control the fire and captures nothing. If she chooses to not burn, she accrues the benefits of slacking, $s$. What makes this a dilemma for individuals is the assumption that $b>s$; the individual net payoffs for collectively burning fields outweigh the individual net payoffs when fields are not burned. How can people work together to reap the larger benefits that require coordination? Does the threat of "the end of the world" motivate individuals to coordinate their actions? Beliefs about such costs might increase the likelihood of choosing to join in with field burning activities. In other words, collective pressure and religious appeals might motivate individuals to opt for the riskier - but more profitable - coordination strategy.

In this example, appeals to the spiritual realm and the end of the world might increase the likelihood of opting for the cooperative option of burning fields with your community. In contrast to our putative model of Martu field burning, our next example has been explicitly modeled as a social dilemma by ethnographers. There, the religious "solution" in the system is not beliefs, but an institutional mechanism that efficiently motivates and generates coordination between individuals. 


\subsection{Water temples of Bali}

The Balinese water temple ecosystem has been extensively studied by Lansing et al. (Lansing \& Kremer, 1993, Lansing \& Miller, 2005, Lansing, 2007 Lansing et al., 2017). This research focuses on the inherent coordination problem faced by Balinese rice terrace farmers. Table 2 represents this problem in the form of a payoff matrix that details the conflicts of interest between two farmers (or farming groups). One lives upstream and one lives downstream. They can choose between two different times to plant their rice. Water comes down the mountain, ensuring that the upstream farmer can use the stream first, depleting it by factor $d$. Therefore, if both farmers plant their rice at the same time, there will be a loss for the downstream farmer since the water will be depleted. Lansing and Miller (2005) assume that threat of pests is reduced if both farmers plant simultaneously because pests can simply migrate from fallow to nearby planted fields. By contrast, if all the fields in a given area are fallow at the same time, pests will have nowhere to opportunistically migrate to and will die off. So, if farmers plant in a staggered, step-wise fashion, both of their yields are reduced by $r$, the pest-consumption factor. Therefore, it is always in the upstream famer's best interests to plant simultaneously with the downstream farmer. However, it is only in the best interests of the downstream farmer to coordinate planting when $r>d$; if the costs of water depletion are worse than those associated with pests, then it makes sense to accept the costs of pests and not coordinate.

\begin{tabular}{ccc}
\hline \hline & Simultaneous & Staggered \\
\hline Simultaneous & $1,1-d$ & $1-r, 1-r$ \\
Staggered & $1-r, 1-r$ & $1,1-d$ \\
\hline \hline
\end{tabular}

Table 2: Payoff matrix for Balinese coordination problem (adapted from Lansing \& Miller 2005). First payoff in each cell is the payoff for the player on the left side of the table (the upstream player), second is for the player on the top of the table (the downstream player).

The practical question of how to maximize everyone's yield, then, is: how 
can we get upstream farmers to give up some water so that the downstream farmers' crops improve to the point that they are willing to coordinate to reduce pests? The answer, according to Lansing et al., is water temples: they function as structured, spiritually sanctioned forums for coordination and forging pacts sealed with ritually-induced bonds. Balinese farmers meet at temples with the desire to honor various deities, receiving small ceremonial distributions of "holy water" (not irrigation water) in return. As these temples exist in a much wider temple network, they have the capacity to maintain a remarkably complex coordination system over vast areas, timing and synchronizing planting on the basis of ritual performance and holy water distribution. Each temple coordinates the planting and harvesting cycles of the farms in its area, called a "subak." Here, the subak is not merely a set of beliefs or appeals that might induce cooperation. Rather, the subak is a community and the religious order facilitates the kind of coordination required to maximize everyone's yields rather than those conveniently located closer to water sources.

Lansing (2006) "wonders whether institutions like water temples exist elsewhere in the world, and if so, what form they might take. Perhaps, like the water temples, they are regarded as religious institutions that can be safely ignored by planners and engineers" (87). Indeed, like the Martu, the Balinese alter their physical landscape in coordinated ways to reap the benefits of collective action and mobilization. We suspect similar religious institutions do exist, and that evolutionary and cognitive scientists miss opportunities to observe them if they avoid rich ethnographic work along the lines of Lansing et al. (see also Sosis, 2009, for further discussion). In fact, the opportunity to explore such a possibility brought one of us to the field. In the following case, spirits function as mediators of human relationships and exploitable resources and ritual sites are strategically located on resources and territorial boundaries.

\subsection{Tyvan spirit-masters}

Local spirits, "spirit-masters," in the Tyva Republic of Siberia care about rituals and the preservation of natural resources such as game and water (Purzycki 
2011, 2016). The rituals that they care about take place on territorial borders, at mineral springs, and lakes (Purzycki, 2013b) and Tyvans encourage each other to keep these areas clean. Furthermore, in some regions considered to be the territories of the spirit-masters, hunting is strictly forbidden (Donahoe 2006, 120). In other words, behaviors associated with spirits and their behavioral corollaries are largely distributed near markers of negotiated territory and at other discrete exploitable resources. We illustrate these scenarios in Figure 2 .

In this illustration, there are two yurt encampments (1 and 2). By necessity, both are located by water sources. In addition to a river, one camp stands by a natural spring, marked with $\mathrm{C}$. These two camps recognize their established territories, marked by a devotional cairn at B. One "territory" is the spirits' land (marked by A) where hunting is forbidden. This illustration is a condensation and simplification of real, observed scenario ${ }^{3}$ many Tyvans other Inner Asian ethnic groups are bound by a common, ancient religious system that entertains the possibility that spirit-masters inhabit the landscape. Individuals who fail to pay respect to the spirits in the locally appropriate manner risk misfortune. In other words, cognition about the moral interests (Boyer, 2000, Purzycki et al. 2022 ) and potential punishments (Johnson, 2005, 2016) of supernatural agents is contextually triggered, spatially distributed, and grounded in local rituals and resources. Indeed, as in the previous sections, we can model each of these scenarios as corresponding to a different social game.

We model Scenario A as a dilemma that revolves around over-exploitation, where it is tempting to hunt deer. In this territory, hunting is off-limits because this is the "spirits' land," but it is in individuals' interests to hunt there anyway, especially considering the difficulty of monitoring others' behavior (or of determining where gunshots are coming from, if they're audible at all). Hardin's (1968) "Tragedy of the Commons" famously offered a dismal portrait of how

\footnotetext{
${ }^{3}$ Purzycki has directly observed and reported on Scenarios B and C, while Scenario A is derived from stories, by implication, and reports by Donahoe (2006).
} 


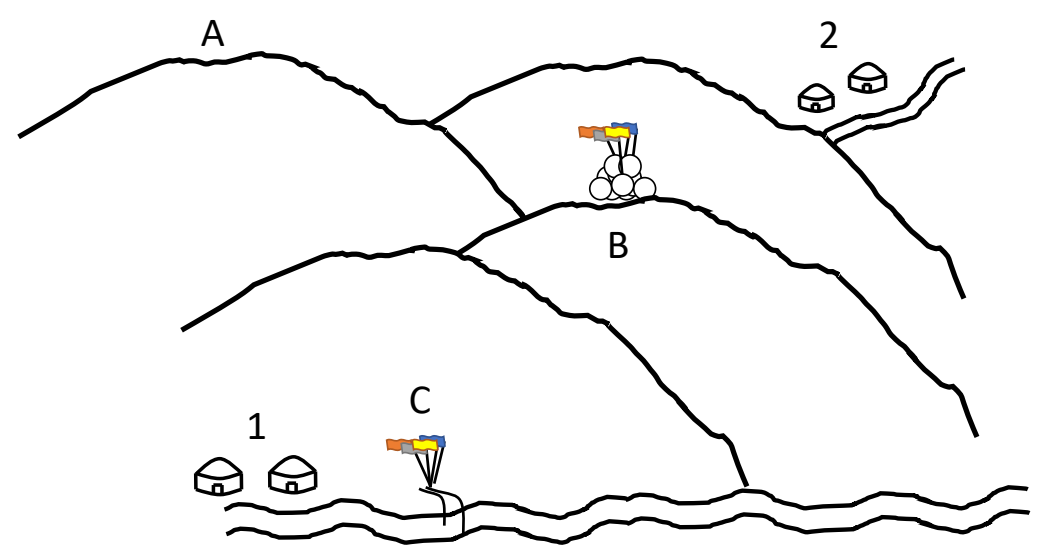

Figure 2: Three scenarios on the relationship between spirit-masters, ritual, and resource in Tyva.

such self-interested behavior can lead to the destruction of common-pool resources when top-down governance is absent (cf. Ostrom, 2015).

We use the Prisoner's Dilemma to model this problem (Table 3). Players can either hunt or forgo hunting. One person could easily defect and continue killing deer, only to effectively wipe out the population ${ }^{4}$ Without restraint, two people hunting would wipe out the deer population even more quickly. However, if both people agree to not hunt there - possibly motivated by a territorial spirit's threat of punishment - the land may ultimately have more reliable returns in the future (since deer migrate too). In other words, spiritual punishments can alter the payoff structure (Johnson \& Krüger, 2004, Johnson, 2016) so that hunting appears to be more costly than forgoing the hunt.

Scenario B concerns territorializing land, which has long been recognized as an effective solution for reducing costly conflict between individuals or groups ¡who have a clear interest in expansion (Dyson-Hudson \& Smith, 1978, May-

${ }^{4}$ Formal models often include discount parameters that adjust the value of subsequent interactions, or some time constraint parameter that toggles the likelihood of interactions changing through time (Axelrod| 1984). Depending on one's questions, the availability of a game might be represented with one of these parameters. 


\begin{tabular}{ccc}
\hline \hline & Forgo & Hunt \\
\hline Forgo & 3 & 1 \\
Hunt & 4 & 2 \\
\hline \hline
\end{tabular}

Table 3: Payoff matrix for Camp 1 in Scenario A: Tragedy of Commons as modelled as the Prisoner's Dilemma from Romagny et al. 1997, Payoffs are for Camp 1.

nard Smith, 1982, pp. 151-161). In this scenario, it is in both parties' best interests to expand their territory. Properly functioning borders can prevent or limit expansion, but keeping territorial borders requires maintenance. A rich literature (e.g., Heap et al., 2012, Mesterton-Gibbons \& Adams, 2003) suggests that landmarks can reduce costs associated with border maintenance among non-human animals. That is, physical-but non-obstructive-indices of borders can function as a reminder of territorial ownership and reduce the likelihood of aggressive conflict. In the context of human territories where borders are not always easy to monitor and therefore maintain, localizing the presence of a powerful deity through ritual acts can be a strategic way of maintaining borders in the absence of effective secular punishment.

\begin{tabular}{ccc}
\hline \hline & Relent & Fight \\
\hline Relent & $\frac{v}{2}$ & 0 \\
Fight & $v$ & $\frac{v-c}{2}$ \\
\hline \hline
\end{tabular}

Table 4: Payoff matrix for Camp 1 in Scenario B: Territory as Hawk-Dove Game. Payoffs are for Camp 1.

As detailed in Table 4, we can model territorial conflict using the Hawk-Dove game (Maynard Smith, 1982, 147-166; cf. Hare et al. 2016). Here, two agents compete over a resource with a specific value, $v$. Camps 1 and 2 could both fight, incurring the costs of fighting, $c$, but with only a $50 \%$ chance of winning. One who relents to an aggressor acquires nothing, and the aggressor gets everything. If both camps choose to relent, they divide the land by half. In this scenario, the only conditions under which Relenters can outcompete Fighters 
are when the costs of fighting outweigh the value of the resources $(v<c)$. In the case of Tyva, placing a spiritual marker on a territorial border might reduce the temptation to engage in risky territorial expansion, turning potential Fighters into Relenters (at least proximately and psychologically). Indeed, when Tyvans are directly asked, spirit-masters are treated as knowledgeable, punitive, and interested in both the ritual and general moral behavior of individuals in their vicinity (Purzycki, 2011, 2013b). Fear of supernatural punishment may therefore increase the perceived costs of aggressive expansion (which entails violating the sacred boundary cairn rites) and therefore facilitate the proliferation of Relenters. Tyvans perceive ritual participants to be more broadly trustworthy than those who don't participate (Purzycki \& Arakchaa, 2013). If disrespecting the spirits is tantamount to disrespecting communities and their rules (Rappaport 1999), it would make sense to convey and adopt the idea that such disrespect would bring misfortune. Indeed, Tyvans believe that bad luck strikes travelers who fail to stop and leave a token of their presence when they encounter cairns.

The related scenario $\mathrm{C}$ echoes any system where outsiders are expected to pay their respects to spirits before extracting others' renewable resources (e.g., Jordan, 2003 Watanabe, 1972). In this scenario, Camp 2's water supply is temporarily depleted, so water must be acquired elsewhere. When local rivers get dirty, people might collect water at neighboring mineral springs. Thus, Camp 2 must travel to someone else's territory to get water. Prior to extracting the water, Camp 2 will perform rites at the mineral spring to pay their respects to the spirit-master of the spring. Camp 2 must convey that they do not have exploitative or aggressive intentions and that they are in Camp 1, where they should not be, simply for water. Conveying deference to spirits implies the likelihood of deference to other local rules, and thus there is no reason for hostility, especially since water is readily available in Camp 1. In this way, a small gesture of respect to the local spirits may decrease the chances of inflaming social tensions between camps.

Spirit-master concepts, evident in all three of these scenarios, are bundled together with corollary processes such as mentalizing Andersen, 2019; Guthrie 
1980), punishment (Johnson \& Bering, 2006), and moralizing (Boyer, 2000

Purzycki, 2011, 2013a, Purzycki et al., 2022). In Tyva, strategically distributed indices trigger these bundles, as well as behavioral expressions of commitment. In other words, the coupling of religious beliefs and practices (Purzycki \& Sosis 2013 ) systemically conforms to particular social dilemmas. With the expertise and inspiration of shamans and other religious experts, communities collectively and ritualistically sanctify and re-sanctify these indices regularly and therefore reinforce the relationships between cognition, cultural beliefs, motivations, and behaviors, and the relative harmony offered by sustained cooperation. Considerable work shows that a variety of mechanisms, such as supernatural punishment (Johnson, 2005; Lang et al., 2019; Shariff \& Norenzayan, 2007) and ritual (Power, 2017; Sosis \& Bressler, 2003, Soler, 2012, Xygalatas et al., 2013), can induce the cooperative options in these dilemmas, contribute to their proliferation, and increase the chances that individuals transmit and retain the kinds of information required to profitably engage in social institutions.

Such mechanisms are manifest in Tyva. With respect to Scenarios B and C, there is evidence that Tyvan beliefs and practices co-vary with social behavior; rituals have been shown to convey trustworthiness to observers (Purzycki \& Arakchaa, 2013), and the more people claim spirit-masters know, the more they give to local community members - at the expense of distant co-religionists - in experimental games (Purzycki \& Kulundary, 2018). However, it remains to be seen whether or not Scenario A, where individuals might forgo hunting because of spiritual sanctions, is adequately accounted for by spiritual sanctions. Indeed, a longstanding debate continues to rage about the so-called "ecologically noble savage" and whether or not traditional religions somehow contribute to the preservation of nature (Hames, 1991, 2007; Smith \& Wishnie, 2000).

Yet, there is considerable experimental research showing that religiosity is related to self-restraint and self-control (Morgan, 2019, Ruffle \& Sosis, 2020 Sasaki \& Kim, 2021, Sosis \& Ruffle, 2003, Tian et al., 2018). This suggests that it is plausible that Tyvans are more likely to forgo hunting when the injunction against it is associated with spirit-masters. Unfortunately, we have no data 
beyond anecdotes $5^{5}$ Nevertheless, there are general proscriptions against hunting in particular areas. Whether or not these proscriptions actually encourage hunters to restrain themselves and whether or not this affects the deer populations in any systematic way remains to be established with more specified theoretical models and focused empirical assessments. In summary, there are many reasons both direct and implied to suspect religious taboos would decrease overexploitation, but subsequent work is required to more rigorously assess this possibility. There are, however, at least two other case studies that reveal that religious beliefs are associated with the active maintenance of resources, namely, the forest spirit beliefs of the Batak from Palawan Island and the Itza' Maya.

\subsection{Forest spirits of the Batak and Itza' Maya}

Another ethnographic case study on spiritually-sanctioned resource management comes from Eder's (1997; 1999) work with the Batak people of Palawan Island, the Philippines. While, traditionally, the Batak lived in isolated and mobile family groups subsisting as hunter-gatherers, contact with the greater Philippine society and migrant farmers has dramatically changed their social environment. Yet, parts of the traditional Batak lifeway persist. One sustained set of traditional beliefs and practices pertains to the Batak's perceived connection with their natural surroundings. As in many traditional foraging societies (e.g., Bird-David, 1999, Rossano, 2007), the Batak possess intricate knowledge about the local ecology and view themselves in close reciprocal relationships with the forest, its plants, animals, and spirits. Importantly, the forest spirits

\footnotetext{
${ }^{5}$ Some anecdotes suggest that while the relationship between spiritual punishment and overhunting is explicit, beliefs and their underlying motivations variably moderate behavior. For example, one elderly man laments that "Taiga gives to you and taiga takes it away. I am blind now, it's my fault. I often hunted, sometimes too much, a passion seized me. I took a lot from taiga, now I have been paying for my bad attitude to taiga. The female master punished me for this" (Arakchaa 2009 50). Though it's left to the imagination what would have happened in the absence of this taboo against hunting too much, the taboo did not appear to work very well in this individual's case.
} 
are regarded as "caretakers" of the forest and can assume both benevolent and malevolent forms. The spirits are usually permissive about letting the Batak forage in the forest; however, if forest resources are collected in excessive amounts, not fully utilized, or otherwise go to waste, the spirits get upset and punish the transgressor. Indeed, simply making fun of animals or disrespecting the forest in other ways will attract the wrath of the spirits. Since the threshold of violation as well as the form of the punishment itself are vague, almost any kind of malady and misfortune can be interpreted as spiritual retribution (Eder, 1997, 10-11). Note, too, that punishing misbehavior is strictly the responsibility of the spirit, in that there are otherwise no formal institutions or social sanctioning in place to deter exploitation (Eder, 1997, 11, 28).

Honey and wild pig meat are central to Batak subsistence. Interestingly, the Batak conceive of specific spirits dedicated to the protection and proliferation of honeybees and pig populations. For instance, if honey is wasted or a hive is disturbed or destroyed (regardless of intent), the relevant spirit will punish the responsible forager with illness, accidents, or even death. The spirit might also send the bees away, making honey unavailable for a time. In that case, a "honey ritual" is required, which involves more than two weeks of collective "good behavior" where interpersonal qualms and conflicts are avoided, and people are mandated to only "think cleanly" about their neighbors (Eder, 1997, 16-17). Similar spiritual sanctions and appeasing rituals ensue if pigs are killed but not properly respected and fully utilized (18). Eder (ibid.) argues that these spiritual beliefs directly contribute to the sustainability of the Batak lifeways. The Batak way of life stands in contrast to Filipino migrants who view the forest not as an agent to be respected but as a resource to be exploited and, as a result, engage in resource-depleting foraging and farming.

While one must remain careful not to romanticize indigenous people's ways of life when evaluating such ethnographic reports Angsongna et al., 2016; Hartberg et al. 2016, see Willerslev (2007) for an example of spirits condoning overexploitation; see also Alvard 1994; Smith \& Wishnie 2000), the ethnographic record is brimming with similar instances of spiritually sanctioned conservation 
systems, at least hinting at causal implications to be tested in future research.

Indeed, a strikingly similar case to the Batak can be found in Atran et al.'s (2002) work among three neighboring rain forest groups in the Maya lowlands of Guatemala. As with the Batak, the indigenous Itza' Maya, have few formal institutions to appeal to but practices the most sustainable agroforestry (e.g., in terms of tree cover and biodiversity) among the three groups, the other two being migrant groups in the area. Importantly, only the Itza' perceive themselves to be in a fully reciprocal relationship with the forest and view the forest spirits as punitive of exploitation and disrespect toward the local ecology.

The Batak and Itza' cases lend themselves to game theoretic analysis. Indeed, Atran et al. (2002) explicitly make this point. Imagine a very simple set of payoffs where people can either exploit forest resources indefinitely for a high benefit, $B$, or self-regulate for a lesser benefit, $b$, and that there is no sanctioning either way (recall that neither the Batak nor the Itza' rely on secular alternatives for deterring forest exploitation; punishing over-exploitation is solely the domain of the spirits). This idealized payoff matrix-let us call it the "Forest/Other people Game" — poses no dilemma in the short-term; as game strategies, Exploit will always outcompete Self-regulation until resources run out.

Imagine now a different permutation, the "Forest Spirit Game," where instead of playing against the forest or other people, the Batak/Itza' now play against punitive forest spirits (cf. Atran et al., 2002, 440). As shown in Table 5 spirits might Punish preemptively, $-c$, even when people Self-regulate, but Punish more severely if people Exploit the forest, $-K{ }^{6}$ Assuming widespread belief in spiritual sanctions and no outside competition for land or resources (but see discussion below), the perceived threat of spiritual punishment presents an alternative set of payoffs, $B-K<b-c$, where the Batak/Itza' are now better

\footnotetext{
${ }^{6}$ Our assumption that $K>c$ is reasonable because perceived supernatural retribution, $K$, involves costly ritual appeasement in addition to the serious illnesses, accidents, and deaths that might be linked to $c$.
} 
off Self-regulating instead of Exploiting.

\begin{tabular}{ccc}
\hline \hline & No Punishment & Punishment \\
\hline Self-regulate & $b$ & $b-c$ \\
Exploit & $B$ & $B-K$ \\
\hline \hline
\end{tabular}

Table 5: Payoff matrix for the "Forest Spirit Game". Payoffs are for the Batak/Itza'. See Brams 2007 137-141 for example of a similar "punishment" game.

Taken together, the Batak and Itza' Maya cases complement the other case studies discussed herein by illustrating how appeals to, beliefs about, and rituals devoted toward punitive and watchful spirits can shift cultural attitudes from short-term exploitation of common resources to long-term sustainable lifeways. The game theoretic analysis also makes explicit the conditions under which Self-regulation is predicted to outcompete Exploiting, namely when the perceived cost of Punishment for Exploiting outweighs the perceived cost of Self-regulating, even taking into account the greater benefit from Exploiting compared to Self-regulating. At least among the Itza' (but see also Eder 1997, 10-11), these conditions appear to hold:

A plausible hypothesis is that spirit preferences represent a synthesis of experience accumulated over generations. Violations of spirit preferences can lead to accidents, falling ill, or worse. It matters little if the supernatural threat is real or not: if people believe in it, the threat of punishment becomes a real deterrent. Our research team has witnessed Itza' who have been bitten by deadly pit vipers refuse to be taken for anti-coagulant treatments that could save their limbs or lives, unless they first had a chance to venture into the forest to ask the spirits for guidance or forgiveness (Le Guen et al., 2013, 781, our emphasis).

Finally, both the Batak and Itza' case studies allow for comparisons between the focal cultural groups - the Batak and the Itza', respectively - and migrant 
groups living in the same environments but who lack the relevant beliefs, appeals, and rituals toward the local ecology and the spirits. In both cases, the Batak and Itza' religious systems contribute to sustainable agroforestry, indicating that, at least under certain circumstances, beliefs about gods' concerns can have tractable psychological, social, behavioral, material, and ecological consequences (Bendixen et al. in press; McNamara \& Purzycki, 2020).

\section{Religious Systems Evolving}

\subsection{Summary}

These ethnographic examples-Martu field burning, Balinese water temples, Tyvan rituals, and the religious conservation values and practices of the Tyvans, Batak, and Itza' - each illustrate that religious beliefs and practices can, at the very least, reflect locally important socioecological dilemmas. However, they also show that those same beliefs and practices can actively restructure the payoffs of these dilemmas, by altering perceived costs of selfishness and/or providing a forum required to achieve cooperative solutions. Religions can be useful, in other words, for sustaining lifeways that would not be readily available otherwise.

As we have illustrated, religious systems around the world interact with locally salient games in notably different ways. First, religious systems can improve the chances that people will cooperatively sustain a common resource, for example, by increasing the perceived costs of selfish strategies. This increase in perceived cost, which might be invoked by threats of bad luck or supernatural monitoring and punishment, is sufficient to shift even a minimally risk-averse decision policy away from potentially costly behaviors (McKay et al. 2017). Second, as demonstrated by the Tyvans, Batak, and Itza', we see that various dilemmas attract religious solutions, such as beliefs that motivate a preservation of natural resources. Third, beliefs and practices can also provide the currency (e.g., lizards among the Martu) and context (e.g., territory among Tyvans) to harness the trust-enhancing capabilities of ritual or ritualized obligations. In the 
case of the Martu, associating field burning with spirits and cosmic order may motivate field burning and, in turn, fuel reciprocal commitments. And finally, specific problems may recruit institutional solutions. Among the Balinese, both theory and evidence suggest that religious institutions function to coordinate people in ways that resolve individually costly conflicts of interest.

Together, these examples also show that religious traditions can evolve in ways that are not satisfactorily reducible to individual cognition or transmission processes alone (Purzycki \& Sosis, 2022, cf. Buskell et al. (2019) for more formal treatment of cultural systems' evolution). More general models that formally ignore behavioral payoffs in a given context miss the factors that maintain systems both synchronically and diachronically. Simple game-theoretic models nicely frame and clarify how religion might nudge individual adherents toward opting for cooperative strategies either directly (e.g., through spiritual punishment) or indirectly (e.g., through social institutions). But different societies face different cooperative games, some of which emerge from persistent ecological problems that are associated with the way people acquire resources. Focusing on the transmission of religious concepts and practices without attending to these contextual relations might have heuristic value, but doing so may overlook essential - but more complicated-factors involved in the persistence and evolution of religion.

\subsection{Accounting for change}

If our general approach has merit, religious systems' elements (Sosis, 2019 , 2020 will correspondingly change when the payoff structures of extant problems change and when costly new problems arise. In Figure 3 , religious beliefs and behaviors are dynamically related to the specific kinds of social dilemmas and conflicts communities endure. These problems would recruit the use of novel religious beliefs and practices that can serve as solutions (Bendixen \& Purzycki 2020 Bendixen et al. in press). The diagram in Figure 3 is a crude and oversimplified depiction of how deeper individual-level mental processes co-inform individual beliefs and behaviors, which in turn contribute to shared (group) be- 
liefs and behaviors that then feed back into individual-level cognitive processes once more. Individuals' deeper cognitive processes might generate, constrain, and modify beliefs and behaviors, but those cognitive processes also receive this information as feedback, channeled through locally relevant social and ecological pathways.

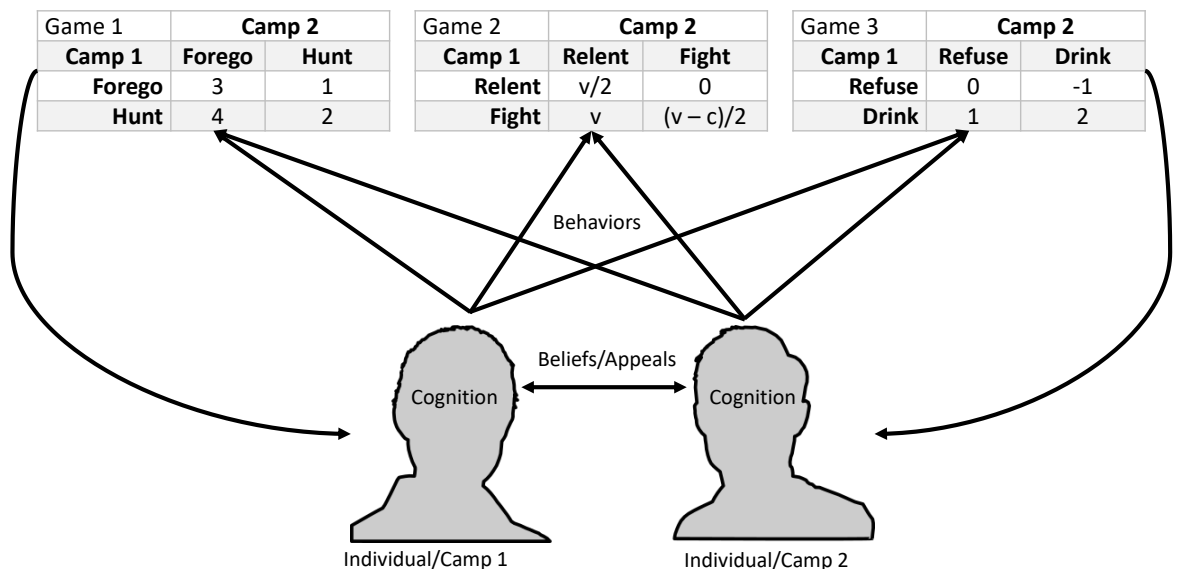

Figure 3: Religion evolving with feedback from social ecology, represented here by payoff matrices. Adapted from Purzycki \& Sosis (2022).

One general prediction of this model is that the cost of social engagement, often experienced as risk of exploitation, affects the content of religious beliefs. As the costs of being exploited increase, we anticipate an increase in religious appeals - that is, appeals to powerful spiritual agents - in a strategic attempt to raise the perceived costs of selfishness (Bendixen et al. in press; Fitouchi \& Singh, 2022, Purzycki \& McNamara, 2016). We similarly expect a proliferation or intensification of religious appeals when communities face novel environmental threats. Accordingly, natural experiments across varying socioecological contexts show an increase in religious expression and commitment-often among relatively non-religious individuals - during times of stress (Henrich et al., 2019 , Sibley \& Bulbulia, 2012, Sosis, 2007; Sosis \& Handwerker, 2011; Vardy \& Atkinson, 2019, cf. Jong et al. 2012, Jong \& Halberstadt 2016 for discussion of the complicated relationship between death anxiety and religiosity). Moreover, 
controlled experiments demonstrate that breaches in mutually beneficial trustreliant interactions can alter the content of believers' models of what angers God in predictable ways (Purzycki et al. 2020).

We also expect that when the costs of interacting with non-cooperators in newly introduced games (i.e., novel conditions) outweigh the corresponding costs of a currently "played" game, religious appeals will increasingly include content that corresponds to the newly introduced problem, especially when the problem is salient in individual minds. To illustrate, interviews reveal that some Tyvans claim that spirit-masters (Purzycki, 2016) and Buddha (Purzycki \& Holland 2019 ) are angered by the alcohol use and abuse that have become a devastating problem in the Tyva Republic. Like the other cases we discussed above, we can frame this particular dilemma in terms of its benefits and costs. The leftmost matrix in Table 6 provides the payoff cells for the general dilemma of whether or not to drink socially. We can model these payoffs primarily in terms of their impact on relative social standing; if drinking entails a social benefit (e.g., the respect that is gained from having a drinking companion), and refusing to drink entails a loss of this social benefit, then $d>c>a>b$. An example of more concrete payoffs is in the middle matrix of Table 6. However, associating divine punishment with drinking behavior can render the costs of drinking much greater than the social costs of not drinking 7 Here, then, $d<c=b<a$ (rightmost matrix in Table 6).

It is worth emphasizing that in Table 6, the shift from the middle matrix to the rightmost matrix is initiated by appeals to a supernatural punishment belief, but this initial nudge away from payoff cell $d$ would be strengthened

${ }^{7}$ See Medicine (2006) for a discussion of drinking behavior among Lakota (Sioux) males where refusing to drink implies femininity and there is abundant peer pressure to imbibe (53-76). See, too, Shermer (2008) for a similar take on taking performance enhancing drugs in athletic competitions. Note that the Koranic source appealed to in discussions of alcohol consumption and gambling (Surah Al-Baqarah 2:219) states that "There is a great harm in both, although they have some benefit for men; but their harm is far greater than their benefit." 


\begin{tabular}{ccc|cc|cc}
\hline \hline & Refuse & Drink & Refuse & Drink & Refuse & Drink \\
\hline Refuse & $a$ & $b$ & 0 & -1 & 0 & -1 \\
Drink & $c$ & $d$ & 1 & 2 & -1 & -3 \\
\hline \hline
\end{tabular}

Table 6: Payoff matrices for perceived costs and benefits of drinking. Left matrix is perceived payoffs of drinking; right is shifting costs to drinking and drinking socially.

by a frequency-dependent shift from widespread approval of drinking toward widespread disapproval of drinking. At a population level, simply learning that a god will punish you for alcoholism is unlikely to curtail consumption. Rather, both changing the incentive structure as well as ensuring the presence of effective institutional and social support with access to resources are more likely to help. Religious appeals can certainly change the perception of the payoffs, then, but we anticipate that the development of fully-fledged religious institutions will be more effective in expediting and strengthening the kind of social support that contributes to abstinence and recovery.

Religions also adapt, adjusting their perceived payoffs, to advance extant meaningful ideologies. Take, for example, the Taiwanese goddess of the sea, Mazu, who became the patron saint of the anti-nuclear energy movement among a group of activists (Shih, 2012). Having found little support among the political parties in power and alienated by a system that failed to address a salient problem, activists consulted an oracle who "predicted" that if it was Mazu's will, the development of another nuclear power plant would be halted. It was, and thus the activists were emboldened to adopt Mazu as their patron saint. Here, then, an already salient problem existed, a secular institution failed to address it, and through the oracular powers of a specialist, a deity was subsequently transformed into a patron saint of a contemporary movement. Believing that one's actions will prevent environmental collapse is likely appreciated as an inequality between resistance and catastrophe. We also predict, therefore, that commitment to the idea that a deity supports one's efforts should offset the perceived costs of engaging and resisting industry and the state. 
A related example of religious evolution is the real and perceived expanding association between environmental preservation and the Abrahamic faiths (see Taylor et al., 2016, White, 1967). More specifically, while the Pope's encyclical Laudato si' likely increased Catholic perception that environmental conservation is God's will, it is much less likely such beliefs would have been adopted if so many Catholics were not already aware and concerned about the environment. In other words, religious change is not random. Had the Pope or the Mazu oracle instead expressed concern about bunny-rabbit invaders from Mars, participation in these religious institutions would likely have declined.

\subsection{Accounting for failure}

Religious systems fail for a host of reasons (Rappaport, 1999 Sosis, 2019 Turpin \& Lanman, 2022). While they can mitigate local challenges to cooperation and coordination, we stress that their benefits are conditional on the system's relationship to its context. In other words, they are not always optimal and in fact appear to exacerbate problems as well. Consider again the Itza' Maya. In a follow-up study, Le Guen et al. (2013) document how Itza' beliefs involving protective and punitive forest spirits are rapidly being undermined by inter-generational change and external influences, in particular competition from non-native immigrants with a more exploitative stance toward the environment. Among younger Itza', this resulted in shifts away from viewing themselves in a reciprocal relationship with the forest and its resources and toward short-term monetary incentives. Thus, according to Le Guen et al. 2013, the "Itza' may be subsidizing their own cultural extinction...to the demise of the forest commons" (p. 789; for detailed discussion of a similar case study, see Eder 1997, p. 19-31). Further, although traditional medicine practitioners in small-scale societies are often shamans and religious healers (Winkelman, 2014), Western medicine practitioners frequently outcompete them for first recourse for ailments (Blackwell, 2009 Lightner et al. 2021). 


\subsection{Conclusion}

In conclusion, while the general content of religious appeals might partially account for their dispersion (Fitouchi \& Singh, 2022, Purzycki \& Willard, 2016), their transmission and retention are likely expedited due to their correspondence to pressing and perceived costs that are already present; religious systems draw attention to threats that already have a prior precedence in a community (Bendixen \& Purzycki, 2020, Bendixen et al., in press, Purzycki \& McNamara 2016). The adoption of novel beliefs is also constrained and facilitated by the extant cultural milieu (Buskell et al., 2019) and corresponding psychologically salient social dilemmas. But the spread of beliefs is not enough to make changes in behavior, of course. Instead, beliefs must trigger, ontogenetically habituate, and naturalize the motivation to behave in locally contingent, self-restrained ways that facilitate cooperation.

As illustrated, features of religious behaviors also adjust to particular conditions. To the extent that these mechanisms contribute to survival and reproduction, we can - by the most critical standards available - construe such systems as adaptive. While the long-term evolution of any social system often escapes precise description, and different evolutionary processes could have been behind the convergent phenomena social scientists study (see issues of equifinality discussed in Barrett, 2019, Kandler \& Powell, 2018; Von Bertalanffy, 1969), we expect that actively assessing such systems will only enrich the field.

\section{Acknowledgements}

For generous support, BGP, TB, and ADL thank the Aarhus University Research Foundation and RS thanks the James Barnett Endowment. We thank two anonymous reviewers for their feedback.

\section{References}

Alcorta, C. S., \& Sosis, R. (2005). Ritual, emotion, and sacred symbols. Human Nature, 16, 323-359. 
Alvard, M. S. (1994). Conservation by native peoples: Prey choice in a depleted habitat. Human nature, 5, 127.

Andersen, M. (2019). Predictive coding in agency detection. Religion, Brain $\mathcal{E}$ Behavior, 9, 65-84.

Angsongna, A., Ato Armah, F., Boamah, S., Hambati, H., Luginaah, I., Chuenpagdee, R., \& Campbell, G. (2016). A systematic review of resource habitat taboos and human health outcomes in the context of global environmental change. Global Bioethics, 27, 91-111.

Arakchaa, T. (2009). Household and Property Relations in Tuva. Boise State University.

Atran, S., Medin, D., Ross, N., Lynch, E., Coley, J., Ek', E. U., \& Vapnarsky, V. (1999). Folkecology and commons management in the Maya Lowlands. 口 Proceedings of the National Academy of Sciences, 96, 7598-7603. doi 10. 1073/pnas.96.13.7598

Atran, S., Medin, D., Ross, N., Lynch, E., Vapnarsky, V., Ek', E. U., Coley, J., Timura, C., \& Baran, M. (2002). Folkecology, Cultural Epidemiology, and the Spirit of the Commons: A Garden Experiment in the Maya Lowlands, 19912001. Current Anthropology, 43, 421-450. doi 10.1086/339528.

Axelrod, R. (1984). The Evolution of Cooperation. New York: Basic Books.

Barrett, B. J. (2019). Equifinality in empirical studies of cultural transmission. Behavioural processes, 161, 129-138.

Bednar, J., \& Page, S. (2007). Can game (s) theory explain culture? the emergence of cultural behavior within multiple games. Rationality and Society, $19,65-97$.

Bendixen, T., Apicella, C., Atkinson, Q., Cohen, E., Henrich, J., McNamara, R. A., Norenzayan, A., Willard, A. K., Xygalatas, D., \& Purzycki, B. G. (in press). Appealing to the minds of gods: Religious beliefs and appeals 
correspond to features of local social ecologies. Religion, Brain $\& 3$ Behavior, . doi 10.31234/osf .io/tjn3e.

Bendixen, T., \& Purzycki, B. G. (2020). Peering into the minds of gods: What cross-cultural variation in gods' concerns can tell us about the evolution of religion. Journal for the Cognitive Science of Religion, 5, 142-165. doi 10 . $1558 /$ jcsr.40951

Bird, D. W., Bird, R. B., Codding, B. F., \& Taylor, N. (2016). A landscape architecture of fire: Cultural emergence and ecological pyrodiversity in australia's western desert. Current Anthropology, 57, S65-S79.

Bird, R. B., \& Power, E. A. (2015). Prosocial signaling and cooperation among martu hunters. Evolution and Human Behavior, 36, 389-397.

Bird, R. B., Tayor, N., Codding, B. F., \& Bird, D. W. (2013). Niche construction and dreaming logic: aboriginal patch mosaic burning and varanid lizards (varanus gouldii) in australia. Proceedings of the Royal Society B: Biological Sciences, 280, 20132297.

Bird-David, N. (1999). "Animism" revisited: personhood, environment, and relational epistemology. Current Anthropology, 40, S67-S91.

Blackwell, A. D. (2009). Life history trade-offs in growth and immune function: The behavioral and immunological ecology of the Shuar of Amazonian Ecuador, an indigenous population in the midst of rapid economic and ecological change. University of Oregon.

Blum, U., \& Dudley, L. (2001). Religion and economic growth: was Weber right? Journal of Evolutionary Economics, 11, 207-230.

Boyer, P. (2000). Functional origins of religious concepts: ontological and strategic selection in evolved minds. Journal of the Royal Anthropological Institute, 6, 195-214. doi 10.1111/1467-9655.00012. 
Brams, S. (2007). Superior Beings. If They Exist, How Would We Know?: Game-Theoretic Implications of Omnipotence, Omniscience, Immortality, and Incomprehensibility. Springer.

Brams, S. J. (2018). Divine games: Game theory and the undecidability of a superior being. MIT Press.

Bulbulia, J. (2004a). The cognitive and evolutionary psychology of religion. Biology and Philosophy, 19, 655-686.

Bulbulia, J. (2004b). Religious costs as adaptations that signal altruistic intention. Evolution and Cognition, 10, 19-38.

Bulbulia, J. (2011). The hypnotic stag hunt. Journal of Cognition and Culture, $11,353-365$.

Bulbulia, J. (2012). Spreading order: religion, cooperative niche construction, and risky coordination problems. Biology \& Philosophy, 27, 1-27.

Bulbulia, J., \& Frean, M. (2010). The evolution of charismatic cultures. Method 8 Theory in the Study of Religion, 22, 254-271.

Buskell, A., Enquist, M., \& Jansson, F. (2019). A systems approach to cultural evolution. Palgrave Communications, 5, 1-15.

Donahoe, B. (2006). Who owns the Taiga?: inclusive vs. exclusive senses of property among the Tozhu and Tofa of southern Siberia. Sibirica, 5, 87-116.

Dyson-Hudson, R., \& Smith, E. A. (1978). Human territoriality: an ecological reassessment. American Anthropologist, 80, 21-41.

Eder, J. F. (1997). Batak resource management: belief, knowledge, and practice. IUCN.

Eder, J. F. (1999). Batak. In R. B. Lee, \& R. Daly (Eds.), The Cambridge Encyclopedia of Hunters and Gatherers. Cambridge University Press. 
Fitouchi, L., \& Singh, M. (2022). Supernatural punishment beliefs as cognitively compelling tools of social control. Current Opinion in Psychology, 44, 252257. doi:https://doi.org/10.1016/j.copsyc.2021.09.022.

Geertz, C. (1973). The interpretation of cultures. Basic books.

le Guen, O., Iliev, R., Lois, X., Atran, S., \& Medin, D. L. (2013). A garden experiment revisited: Inter-generational change in environmental perception and management of the Maya Lowlands, Guatemala: A garden experiment revisited. Journal of the Royal Anthropological Institute, 19, 771-794. doi-10. 1111/1467-9655.12064.

Guthrie, S. E. (1980). A cognitive theory of religion. Current Anthropology, 21, 181-203. doi:10.1086/202429.

Guthrie, S. E. (1995). Faces in the clouds: A new theory of religion. New York: Oxford University Press.

Hacking, I. (1972). The logic of Pascal's wager. American Philosophical Quarterly, 9, 186-192.

Hames, R. (1991). Wildlife conservation in tribal societies. Biodiversity: Culture, conservation, and ecodevelopment, (pp. 172-199).

Hames, R. (2007). The ecologically noble savage debate. Annu. Rev. Anthropol., 36, 177-190.

Hardin, G. (1968). The tragedy of the commons: the population problem has no technical solution; it requires a fundamental extension in morality. Science, 162, 1243-1248.

Hare, D., Reeve, H. K., \& Blossey, B. (2016). Evolutionary routes to stable ownership. Journal of Evolutionary Biology, 29, 1178-1188.

Hartberg, Y., Cox, M., \& Villamayor-Tomas, S. (2016). Supernatural monitoring and sanctioning in community-based resource management. Religion, Brain \& Behavior, 6, 95-111. 
Heap, S., Byrne, P., \& Stuart-Fox, D. (2012). The adoption of landmarks for territorial boundaries. Animal Behaviour, 83, 871-878.

Henrich, J., Bauer, M., Cassar, A., Chytilová, J., \& Purzycki, B. G. (2019). War increases religiosity. Nature Human Behaviour, 3, 129-135.

Jensen, J. S. (2019). What is religion?. (2nd ed.). Routledge.

Johnson, D., \& Bering, J. (2006). Hand of God, Mind of Man: Punishment and Cognition in the Evolution of Cooperation. Evolution-

口 ary Psychology, 4, 147470490600400119. URL: https://doi.org/10.1177/ 147470490600400119, doi:10.1177/147470490600400119.

Johnson, D., \& Krüger, O. (2004). The good of wrath: Supernatural punishment and the evolution of cooperation. Political Theology, 5, 159-176.

Johnson, D. D. P. (2005). God's punishment and public goods. Human Nature, $16,410-446$.

Johnson, D. D. P. (2016). God is watching you: How the fear of god makes us human. Oxford University Press, USA.

Jong, J., \& Halberstadt, J. (2016). Death Anxiety and Religious Belief: An Existential Psychology of Religion. London: Bloomsbury.

Jong, J., Halberstadt, J., \& Bluemke, M. (2012). Foxhole atheism, revisited: The effects of mortality salience on explicit and implicit religious belief. Journal of Experimental Social Psychology, 48, 983-989.

Jordan, P. (2003). Material Culture and Sacred Landscape: The Anthropology of the Siberian Khanty. Walnut Creek, CA: AltaMira Pres.

Kandler, A., \& Powell, A. (2018). Generative inference for cultural evolution. Philosophical Transactions of the Royal Society B: Biological Sciences, 373, 20170056. 
Kendal, J., Tehrani, J. J., \& Odling-Smee, J. (2011). Human niche construction in interdisciplinary focus. Philosophical Transactions of the Royal Society B: Biological Sciences, 366, 785-792.

Laland, K., Matthews, B., \& Feldman, M. W. (2016). An introduction to niche construction theory. Evolutionary ecology, 30, 191-202.

Lang, M., Purzycki, B. G., Apicella, C. L., Atkinson, Q. D., Bolyanatz, A., Cohen, E., Handley, C., Kundtová Klocová, E., Lesorogol, C., Mathew, S. et al. (2019). Moralizing gods, impartiality and religious parochialism across 15 societies. Proceedings of the Royal Society B, 286, 20190202.

Lansing, J. S. (2006). Perfect Order: Recognizing Complexity in Bali. Princeton: Princeton University Press.

Lansing, J. S. (2007). Priests and Programmers: Technologies of Power in the Engineered Landscape of Bali. Princeton University Press.

Lansing, J. S., \& Kremer, J. N. (1993). Emergent Properties of Balinese Water Temple Networks: Coadaptation on a Rugged Fitness Landscape. American Anthropologist, 95, 97-114. URL: http://www.jstor.org/stable/681181.

Lansing, J. S., \& Miller, J. (2005). Cooperation, games, and ecological feedback: some insights from bali. Current Anthropology, 46, 328-334.

Lansing, J. S., Thurner, S., Chung, N. N., Coudurier-Curveur, A., Karakaş, , Fesenmyer, K. A., \& Chew, L. Y. (2017). Adaptive self-organization of Bali's ancient rice terraces. Proceedings of the National Academy of Sciences, 114, 6504-6509. doi 10.1073/pnas.1605369114.

Le Guen, O., Iliev, R., Lois, X., Atran, S., \& Medin, D. L. (2013). A garden experiment revisited: inter-generational change in environmental perception and management of the $\mathrm{m}$ aya 1 owlands, g uatemala. Journal of the Royal Anthropological Institute, 19, 771-794. 
Lightner, A. D., Heckelsmiller, C., \& Hagen, E. H. (2021). Ethnomedical specialists and their supernatural theories of disease. Review of Philosophy and Psychology, (pp. 1-36).

Lightner, A. D., \& Purzycki, B. G. (n.d.). Game theoretical aspects of the minds of gods. In B. G. Purzycki, \& T. Bendixen (Eds.), The Minds of Gods: New Horizons in the Naturalistic Study of Religion. Bloomsbury Publishing.

Maynard Smith, J. (1982). Evolution and the Theory of Games. Cambridge university press.

McNamara, R. A., \& Purzycki, B. G. (2020). Minds of gods and human cognitive constraints: socio-ecological context shapes belief. Religion, Brain $\mathcal{E}$ Behavior, 10, 223-238. doi 10.1080/2153599X.2019.1678510.

Medicine, B. (2006). Drinking and sobriety among the Lakota Sioux. Altamira Press.

Mesterton-Gibbons, M., \& Adams, E. S. (2003). Landmarks in territory partitioning: A strategically stable convention? The American Naturalist, 161, 685-697.

Morgan, J. R. (2019). Religious engagement and varieties of self-regulation: broadening beyond belief and restraint. Ph.D. thesis Boston University.

Nesse, R. (1999). Evolution of commitment and the origins of religion. Science and Spirit, 10, 32-33.

Norenzayan, A. (2013). Big gods: How religion transformed cooperation and conflict. Princeton University Press.

North, D. C. (1990). Institutions, Institutional Change and Economic Performance. Cambridge: Cambridge University Press. Google-Books-ID: oFnWbTqgNPYC. 
North, D. C. (1991). Institutions. Journal of Economic Perspectives, 5, 97112. URL: https://www.aeaweb.org/articles?id=10.1257/jep.5.1.97 doi: $10.1257 /$ jep.5.1.97

Orbell, J., Goldman, M., Mulford, M., \& Dawes, R. (1992). Religion, context, and constraint toward strangers. Rationality and Society, 4, 291-307.

Ostrom, E. (2015). Governing the commons: The evolution of institutions for collective action. Cambridge university press.

Pasquino, P. (2001). Hobbes, religion, and rational choice: Hobbes's two leviathans and the fool. Pacific philosophical quarterly, 82, 406-419.

Power, E. A. (2017). Discerning devotion: Testing the signaling theory of religion. Evolution and Human Behavior, 38, 82-91.

Purzycki, B. G. (2011). Tyvan cher eezi and the socioecological constraints of supernatural agents' minds. Religion, Brain \& Behavior, 1, 31-45.

Purzycki, B. G. (2013a). The minds of gods: A comparative study of supernatq ural agency. Cognition, 129, 163 - 179. doi http://dx.doi.org/10.1016/ j.cognition.2013.06.010.

Purzycki, B. G. (2013b). Toward a cognitive ecology of religious concepts: An example from the tyva republic. Journal for the Cognitive Science of Religion, 1, 99-120.

Purzycki, B. G. (2016). The evolution of gods' minds in the Tyva Republic. Current Anthropology, 57, S88-S104. doi $10.1086 / 685729$.

Purzycki, B. G., \& Arakchaa, T. (2013). Ritual Behavior and Trust in the Tyva Republic. Current Anthropology, 54, 381-388. doi 10.1086/670526.

Purzycki, B. G., \& Holland, E. C. (2019). Buddha as a God: An Empirical Assessment. Method $\& 3$ Theory in the Study of Religion, 31, 347-375. doi 10. 1163/15700682-12341453. 
Purzycki, B. G., \& Kulundary, V. (2018). Buddhism, identity, and class: fairness and favoritism in the tyva republic. Religion, Brain $\&$ Behavior, 8, 205-226.

Purzycki, B. G., \& McNamara, R. A. (2016). An ecological theory of gods' minds. In H. De Cruz, \& R. Nichols (Eds.), Cognitive Science of Religion and Its Philosophical Implications (pp. 143-167). New York: Continuum.

Purzycki, B. G., \& Sosis, R. (2013). The extended religious phenotype and the adaptive coupling of ritual and belief. Israel Journal of Ecology $\&$ Evolution, $59,99-108$.

Purzycki, B. G., \& Sosis, R. (2022). Religion Evolving: The Dynamics of Culture, Cognition and Ecology. Equinox.

Purzycki, B. G., Stagnaro, M. N., \& Sasaki, J. (2020). Breaches of Trust Change the Content and Structure of Religious Appeals. Journal for the Study of Religion, Nature and Culture, 14, 71-94. doi 10.1558/jsrnc.38786

Purzycki, B. G., \& Willard, A. K. (2016). Mci theory: a critical discussion. Religion, Brain \& Behavior, 6, 207-248. doi 10.1080/2153599X.2015.1024915

Purzycki, B. G., Willard, A. K., Klocová, E. K., Apicella, C., Atkinson, Q., Bolyanatz, A., Cohen, E., Handley, C., Henrich, J., Lang, M., Lesorogol, C., Mathew, S., McNamara, R. A., Moya, C., Norenzayan, A., Placek, C., Soler, M., Weigel, J., Xygalatas, D., \& Ross, C. T. (2022). The Moralization Bias of Gods' Minds: A Cross-Cultural Test. Religion, Brain and Behavior, 12, 38-60.

Rappaport, R. A. (1999). Ritual and Religion in the Making of Humanity volume 110. Cambridge University Press.

Romagny, B., Lobry, C., Canalis-Durand, M. et al. (1997). Tragedy of the Commons and Prisonner's Dilemma. Technical Report Universite Aix-Marseille III. 
Rossano, M., \& LeBlanc, A. (2017). Why add the supernatural? Religion, Brain \& Behavior, 7, 375-377.

Rossano, M. J. (2007). Supernaturalizing Social Life: Religion and the Evoq lution of Human Cooperation. Human Nature, 18, 272-294. doi 10.1007/ s12110-007-9002-4.

Rousseau, J.-J. (2016 [1755]). A Discourse on Inequality. Open Road.

Ruffle, B. J., \& Sosis, R. (2020). Do religious contexts elicit more trust and altruism? decision-making scenario experiments. Journal of Economics, Management and Religion, 1, 2050002.

Sasaki, J. Y., \& Kim, H. S. (2021). The ego dampening influence of religion: evidence from behavioral genetics and psychology. Current Opinion in Psychology, 40, 24-28.

Schelling, T. C. (1968). Game theory and the study of ethical systems. Journal of Conflict Resolution, 12, 34-44.

Shariff, A. F., \& Norenzayan, A. (2007). God is watching you: Priming god concepts increases prosocial behavior in an anonymous economic game. Psychological science, 18, 803-809.

Shermer, M. (2008). The doping dilemma. Scientific American, 298, 82-89.

Shih, F.-L. (2012). Generating power in taiwan: Nuclear, political and religious power. Culture and Religion, 13, 295-313.

Sibley, C. G., \& Bulbulia, J. (2012). Faith after an earthquake: A longitudinal study of religion and perceived health before and after the 2011 christchurch new zealand earthquake. PloS one, 7, e49648.

Skyrms, B. (2004). The stag hunt and the evolution of social structure. Cambridge University Press. 
Smith, E. A., \& Wishnie, M. (2000). Conservation and Subsistence in Smalln Scale Societies. Annual Review of Anthropology, 29, 493-524. doi 10.1146/ annurev . anthro.29.1.493.

Soler, M. (2012). Costly signaling, ritual and cooperation: evidence from candomblé, an afro-brazilian religion. Evolution and Human Behavior, 33, 346356.

Sosis, R. (2003). Why aren't we all hutterites? Human Nature, 14, 91127. URL: https://doi.org/10.1007/s12110-003-1000-6. doi 10.1007/ s12110-003-1000-6.

Sosis, R. (2007). Psalms for safety: Magico-religious responses to threats of terror. Current Anthropology, 48, 903-911.

Sosis, R. (2009). The adaptationist-byproduct debate on the evolution of religion: Five misunderstandings of the adaptationist program. Journal of Cognition and Culture, 9, 315-332.

Sosis, R. (2019). The building blocks of religious systems: Approaching religion as a complex adaptive system. In Evolution, Development and Complexity (pp. 421-449). Springer.

Sosis, R. (2020). Four advantages of a systemic approach to the study of religion. Archive for the Psychology of Religion, 42, 142-157.

Sosis, R., \& Bressler, E. R. (2003). Cooperation and commune longevity: A test of the costly signaling theory of religion. Cross-cultural research, 37, 211-239.

Sosis, R., \& Handwerker, W. P. (2011). Psalms and coping with uncertainty: Religious israeli women's responses to the 2006 lebanon war. American Anthropologist, 113, 40-55.

Sosis, R., \& Ruffle, B. J. (2003). Religious ritual and cooperation: Testing for a relationship on Israeli religious and secular kibbutzim. Current Anthropology, 44, 713-722. doi $10.1086 / 379260$ 
Spiro, M. E., Killborne, B., \& Langness, L. L. L. (1987). Culture and human nature. Transaction Publishers.

Taylor, B., Van Wieren, G., \& Zaleha, B. (2016). The greening of religion hypothesis (part two): Assessing the data from lynn white, jr, to pope francis. Journal for the Study of Religion, Nature and Culture, 10, 306-378.

Tian, A. D., Schroeder, J., Häubl, G., Risen, J. L., Norton, M. I., \& Gino, F. (2018). Enacting rituals to improve self-control. Journal of Personality and Social Psychology, 114, 851.

Tonkinson, R. (1991). The Mardu Aborigines: Living the Dream in Australia's Desert. Fort Worth: Holt, Rinehard, and Winston.

Turpin, H., \& Lanman, J. A. (2022). The failure of religious systems. The Oxford Handbook of the Cognitive Science of Religion, (pp. 303-326).

Tuzin, D. (1997). The cassowary's revenge: the life and death of masculinity in a New Guinea society. University of Chicago Press.

Tylor, E. B. (1920). Primitive culture: Researches into the development of mythology, philosophy, religion, language, art, and custom. London: Murray.

Vardy, T., \& Atkinson, Q. D. (2019). Property damage and exposure to other people in distress differentially predict prosocial behavior after a natural disaster. Psychological Science, 30, 563-575.

Von Bertalanffy, L. (1969). General System Theory: Foundations, Development, Applications. George Braziller Inc.

Von Neumann, J., \& Morgenstern, O. (2007 [1944]). Theory of games and economic behavior. Princeton: Princeton University Press.

48 Wallace, A. (1966). Religion: An anthropological view. Random House.

Watanabe, H. (1972). The Ainu. 
${ }_{950}$ Weingast, B. R. (1995). A rational choice perspective on the role of ideas: Shared belief systems and state sovereignty in international cooperation. Politics 83 Society, 23, 449-464.

White, L. (1967). The Historical Roots of Our Ecologic Crisis. Science, 155, 1203-1207. doi $10.1126 /$ science.155.3767.1203.

Willerslev, R. (2007). Soul hunters: Hunting, animism, and personhood among the Siberian Yukaghirs. Berkeley: University of California Press.

Winkelman, M. (2014). Political and demographic-ecological determinants of a institutionalised human sacrifice. Anthropological Forum, 24, 47-70. doi 10. $1080 / 00664677.2014 .860888$

Xygalatas, D., Mitkidis, P., Fischer, R., Reddish, P., Skewes, J., Geertz, A. W., Roepstorff, A., \& Bulbulia, J. (2013). Extreme rituals promote prosociality. Psychological Science, 24, 1602-1605. 